\title{
MENITI TEKS AJARAN HINDU SEBGAI INSPIRASI MEWUJUDKAN PROFESIONALITAS KERJA SESUAI GUNA DAN KARMA
}

\author{
I Gusti Komang Kembarawan \\ Institut Agama Hindu Negeri Gde Pudja Mataram \\ gustikembarawan@gmail.com
}

\begin{abstract}
This study aims to conduct a study of Hindu literary texts that contain teachings about inspiration to realize work professionalism using the basis of guna and karma. The Hindu religious texts used as research data sources are the text of Agastya Parwa, the Vedic scriptures, and the Bhagavadgita. The text that is used as the source of research data is limited to aspects that contain aspects of the division of labor according to guna and karma. This study uses a qualitative descriptive method to analyze Hindu religious texts according to the research focus. More specifically, this study applies content analysis in order to find answers to the formulation of the problem posed. Based on the results of this study, two findings were found. First, the teachings that contain inspiration for work professionalism in Agastya Parwa's text are presented in the form of a dialogue which essentially states that work professionalism is inspired by grouping people based on chess colors. Second, the inspiration in building work professionalism contained in the teachings of the Agastya Parwa text is in harmony with the teachings of the Vedas and the Bhagavadgita, especially in determining professionalism based on guna and karma.
\end{abstract}

Keywords: work professionalism, Agastya Parwa, Vedic scriptures, Bhagavadgita

\begin{abstract}
Abstrak
Penelitian ini bertujuan untuk melakukan kajian terhadap teks susastra Hindu yang mengandung ajaran tentang inspirasi mewujudkan profesionalisme kerja menggunakan landasan guna dan karma. Teks ajaran agama Hindu yang dijadikan sumber data penelitan adalah naskah teks Agastya Parwa, kitab suci Veda, dan kitab Bhagavadgita. Teks yang dijadikan sumber data penelitian dibatasi pada aspek yang mengandung aspek pembagian kerja menurut guna dan karma. Penelitian ini menggunakan metode deskriptif kualitatif untuk menganalisis teks-teks ajaran agama Hindu sesuai dengan fokus penelitian. Secara lebih khusus penelitian ini menerapkan konten analisis dalam rangka untuk menemukan jawaban dari rumusan masalah yang diajukan. Berdasarkan hasil penelitian ini ditemukan dua temuan. Pertama, ajaran yang mengandung inspirasi profesionalisme kerja dalam teks Agastya Parwa disajikan dalam bentuk dialog yang pada intinya mengemukakan bahwa profesionalisme kerja diinspirasikan melalui pengelompokkan masyarakat berdasarkan atas catur warna. Kedua, inspirasi dalam membangun profesionalisme kerja yang terkandung dalam ajaran teks Agastya Parwa memiliki keselarasan dengan ajaran kitab suci Weda dan kitab Bhagawadgita, terutama dalam menentukan profesionalisme yang berdasarkan atas guna dan karma.
\end{abstract}

Kata kunci: profesionalisme kerja, Agastya Parwa, Kitab Suci Weda, Kitab Bhagawadgita 


\section{Pendahuluan}

Teks karya sastra yang diwarisi oleh para pendahulu memiliki nilai yang sangat penting dalam membantu mewujudkan kehidupan sosial yang lebih baik jika diterapkan secara tepat dalam masyarakat pendukungnya. Teks karya sastra merupakan bagian dari sejarah kebudayaan bangsa Indonesia yang menjadi identitas serta merefleksikan nilai-nilai luhur yang telah berlangsung semenjak zaman purba. Hasil-hasil kesusastraan tersebut sudah ada pada zaman purba sampai saat ini diwarisi sebagaimana dikemukakan oleh Soekmono (1981:104-105) bahwa hasil-hasil kesusastraan tersebut terutama yang berasal dari Jawa namun naskah-naskahnya sampai kepada kita didapatkannya di Bali. Hal tersebut disebabkan oleh karena naskah-naskah tersebut ditulis di atas daun lontar yang tidak bisa bertahan sampai berabad-abad dan waktu masyarakat Jawa sudah memeluk agama Islam naskah-naskah tadi tidak lagi mendapat perhatian. Keberadaan masyarakat Hindu di Bali merupakan keberuntungan yang sangat besar karena kitab-kitab lontar tersebut disimpan dengan baik sdan dipelihara terus sedangkan kepandaian menulis di atas daun lontar masih tetap dipertahankan dan penghargaan terhadap kesusastraan lama itu masih menjadi kebanggaan. Naskah-naskah yang sudah tua itu disalin dan diperbaharui, sehingga kesusastraan kuno itu masih saja hidup meskipun hurufnya yang dipakai bukan lagi huruf Jawa Kuno, melainkan huruf Bali. dengan demikian naskah-naskah buah kesustraan jaman purba itu dapat diketahui kembali.

Ditinjau dari waktu perkembangannya menurut Soekmono (1981: 105) kesusastraan jaman kuno itu dapat dibagi menjadi kesusastraan: jaman Mataram (sekitar abad kesembilan dan kesepuluh)jaman Kediri (sekitar abad kesebelas dan abad keduabelas), jaman Majapahit I (sekitar abad keempatbelas, dan jaman Majapahit II (sekitar abad kelima belas dan keenambelas). Adanya dua jaman Majapahit itu didasarkan atas bahasanya yang dipakai. Sampai dengan jaman Majapahit I bahasanya adalah bahasa Jawa Kuno, dan sesudah itu bahasanya adalah bahasa Jawa Kuno tengahan. Termasuk jaman Majapahit II adalah hasil-hasil kesusastraan yang berkembang di Bali (jaman Kerajaan SampranganGelgel) 


\section{Gusti Komang Kembarawan-Meniti Teks Ajaran Hindu sebagai Inspirasi Mewujudkan Profesionalitas Kerja sesuai Guna dan Karma}

Hasil-hasil kesusastraan jaman purba yang sampai kini diwarisi perlu mendapatkan perhatian yang serius. Kendati karya-karya sastra tersebut ditulis pada masa lampau yang dalam konteks sosial sangat berbeda dengan dengan jaman modern seperti sekarang ini, namun di dalam karya-karya sastra tersebut tidak dipungkiri bahwa nilai-nilai luhur yang terkandung di dalamnya dapat dijadikan inspirasi khususnya dalam upaya membangun kepribadian dan jati diri manusia yang beradab. Karya-karya sastra yang disusun pada masa kuno sarat akan nilai-nilai keagamaan yang dikemas dalam bahasa yang estetik sehingga disamping dapat menikmati karya tersebut dari segi keindahan bahasanya juga akan dapat diserap nilai-nilai religius yang terkandung di dalamnya.

Upaya untuk menggali nilai-nilai religius yang tersurat dan tersirat dalam teks-teks kuno baik yang diproduksi oleh para sastrawan di Indonesia maupun yang berasal dari luar Indonesia, khususnya dari India sangat perlu dilakukan dalam rangka untuk menambah khasanah pengetahuan-pengetahuan religiusitas. Hal tersebut tidak terlepas dari upaya untuk merevitalisasi nilai-nilai luhur yang terdapat dalam teks-teks tersebut yang dapat digunakan sebagai sumber ajaran dan dijadikan pedoman dalam rangka merealisasikan tujuan hidup di dunia ini. Revitalisasi nilai-nilai luhur yang terkandung dalam teks-teks kuno dalam konteks kehidupan bermasyarakat diwujudnyatakan dengan mengaktualisasikan nilai-nilai luhur tersebut dalam membangun keselarasan dalam interaksi sosial di lingkungannya.

Ditinjau dari keberadaannya, teks-teks kuno yang sampai saat ini masih diwarisi untuk di Wilayah Indonesia, khususnya di Bali dan Lombok jumlahnya relatif banyak. Teks-teks tersebut disimpan di berbagai tempat seperti di lingkungan pribadi dan di di lembaga dokumentasi negara. Teks-teks yang tersimpan di lingkungan pribadi umumnya berada di lingkungan keluarga seperti griya, puri, atau di rumah-rumah pribadi. Sedangkan yang tersimpan pada lembaga dokumentasi negara seperti yang ada di Gedong Kertya (Singaraja), Pusat Dokumentasi Kebudayaan (Pusdok Denpasar), Fakultas Sastra Universitas Udayana, Universitas Hindu Indonesia, Institut Hindu Dharma Negeri Denpasar, dan yang lainnya.

Dalam rangka untuk merevitalisasi nilai-nilai luhur yang terdapat dalam teks-teks tersebut pertama-tama yang harus dilakukan adalah mengetahui content atau isi yang terkandung dalam teks-teks tersebut. Content atau isi yang terkandung dalam teks-teks 


\section{SOPHIA DHARMA, Vol 4, No. 1, Mei 2021}

tersebut selanjutnya diklasifikasikan sesuai dengan aspek-aspek yang diajarkannya seperti aspek relegius, aspek filsafat, aspek sosial, aspek estetika, dan yang lainnya. Hal ini didasari bahwa dalam sebuah karya kuno, di dalamnya terdapat berbagai aspek yang menyangkut nilai-nilai luhur yang dapat dijadikan pedoman hidup. Hal ini terutama yang berkaitan dengan mewujudkan kehidupan yang lebih baik berdasarkan profesionalisme. Berkaitan dengan itu dalam studi ini diambil teks karya sastra yang berkaitan dengan sumber ajaran agama Hindu yang menekankan aspek guna dan karma sebagai landasan untuk menuju pada kinerja yang profesional.

Salah satu teks kuno yang sampai saat ini diwarisi khususnya yang di dalamnya mengandung ajaran agama Hindu yang mengajarkan profesionalisme yang menyangkut guna dan karma adalah Agastya Parwa. Agastya Parwa mengandung nilai-nilai luhur dalam berbagai aspek seperti ajaran tentang karma pala, yoga, kelepasan, sosial dan sejumlah aspek lainnya yhang dapat digunakan sebagai pedoman dalam berperilaku. Berkenaan dengan sejumlah aspek yang terkandung di dalam teks Agastya Parwa dalam penelitian ini akan dikaji satu aspek saja yakni yang berkaitan dengan aspek mewujudkan kehidupan sosial yang professional berdasarkan pembagian kerja. Rumusan permasalahan dalam studi ini adalah (1) bagaimana nilai-nilai profesionalisme yang diajarkan dalam teks Agastya Parwa? (2) Bagaimana kaitan nilai-nilai profesionalisme kerja dalam teks ajaran Agastya Parwa dengan ajaran kitab suci Veda? (Manfaat hasil penelitian ini diharapkan memberikan konstribusi bagi mewujudkan disiplin kerja yang lebih baik.

\section{Metodologi Penelitian}

Penelitian yang berkaitan dengan tinjauan aspek sosiologis dalam teks Agastya Parwa merupakan model penelitian studi pustaka. Objek penelitian ini adalah naskah yang dipandang menurut teks yang harfiah. Teks Agastya Parwa diselidiki dalam aspek sosiologisnya sejauh yang membahasaakan suatu visi mengenai kedudukan manusia dalam kelompoknya. Peneliti dalam hal ini membahas teks Agastya Parwa yang telah dialihbahasakan dari Bahasa Jawa Kuno ke dalam bahasa Indonesia.

Sumber utama data yang dikumpulkan dalam penelitian ini adalah teks Agastya

Parwa terutama ajaran yang terkandung di dalamnya yang berkaitan dengan aspek 
sosiologi. Adapun fokus utama aspek sosiologi yang dianalisis dalam penelitian ini adalah yang menyangkut interaksi sosial yang bertalian dengan kelas-kelas yang didasarkan atas fungsionalisasi individu di dalam kelompoknya. Aspek sosiologis tersebut berupaya untuk diungkap dalam rangka untuk memberikan pemahaman kepada masyarakat Hindu decara umum sehingga konflik sosial yang dimotori oleh sistem pembagian kelas dapat diantisipasi.

Penelitian ini dalam upaya untuk menganalisis data menggunakan metode interpretasi. Merujuk pada Sudarto (1997: 109-110) dalam interpretasi peneliti melakukan pendalaman penyelaman terhadap teks agar dapat ditangkap arti dan nuansanya secara khas yang dimaksudkan oleh penulis naskah tersebut. Berkaitan dengan penelitian ini, metode interpretasi difungsikan untuk menafsirkan data yang diperoleh dalam teks Agastya Parwa khususnya untuk mengkaji aspek sosiologis. Setelah dilakukan interpretasi diharapkan akan memperoleh pemahaman baru berkenaan dengan aspek-aspek sosiologis yang terkandung dalam teks Agastya Parwa.

\section{Hasil dan Pembahasan}

\section{Inspirasi Profesionalitas Kerja dalam Teks Ajaran Agastya Parwa}

Penelitian ini memokuskan pada teks ajaran Agastya Parwa yang digunakan sebagai sumber inspirasi mewujudkan profesionalitas kerja. Naskah Agastya Parwa dalam penelitian ini digunakan sebagai teks yang di dalamnya mengajarkan ajaran yang mengandung inspirasi mewujudkan profesionalisme kerja yang dikandung dalam sloka yang disajikan dalam bentuk dialog antara dua tokoh yakni Bhagawān Agastya dengan putranya yang bernama Sang Dådhasyu. Rupanya nama kitab Agastya Parwa diambil dari nama salah satu tokoh yang digunakan dalam dialog yang menyampaikan ajaran. Rupanya dialog antara Bhagawān Agastya dengan putranya dalam naskah Agastya Parwa berkaitan dengan sejumlah aspek khususnya yang berkaitan dengan penyampaian ajaran Hindu.

Merujuk pada Sura dkk. (2002:iii) Bhagawān Agastya terkenal dalam sastra-sastra Sansekerta sebagai seorang Bhagawān yang menyebarkan agama Hindu ke India Selatan sampai ke Nusantara. Beliau adalah seorang Bhagawān pengelana yang tidak kembali pulang. Berdasarkan hal tersebut dapat diketahui bahwa Bhagawān Agastya memang berasal dari India dan sangat berperan dalam menyebarkan agama Hindu baik di India 


\section{SOPHIA DHARMA, Vol 4, No. 1, Mei 2021}

khususnya di India Selatan dan di wilayah Nusantara. Masa hidup beliau digunakan dalam pengembaraan, dan bahkan beliau ketika mengakhiri masa hidupnya berada di dalam pengembaraannya.

Sebagaimana dikemukakan lebih lanjut oleh Sura dkk. (2002:iii) kepastian waktu penulisan kitab Agastya Parwa tidak diketahui dengan tepat karena tidak ada menyebutkan angka tahun atau juga tidak ada membicarakan hal-hal yang berkaitan dengan masa kerajaan atau nama raja. Menurut R.M.N. Poerbotjaraka Agastya Parwa dikategorikan sebagai Kitab-Kitab Jawa Kuno Golongan Tua. Menurut pendapat beliau susunannya menyerupai susunan kitab Brahmāndapurāna. Demikian juga isinya Kitab Brahmāndapurāna seumur dengan Kitab Sang Hyang Kamahāyanikan yang ditulis pada zaman Empu Sindok di Jawa Timur. Dengan demikian, agaknya umur Kitab Agastya Parwa mendekati umur kitab Brahmāndapurāna.

Isi kitab Agastya Parwa secara umum berkaitan dengan asal-usul para resi, para raja, dan orang-orang terkenal dalam cerita-cerita Hindu. Di dalam cerita-cerita yang berkaitan dengan asal-usul ini disisipkan bermacam-macam ajaran agama Hindu terutama tentang karma phala. Karma phala itu akibat dari tri kaya yaitu tiga perbuatan yang dilakukan oleh manusia yang terdiri dari kāyika, yakni perilaku yang yang dilakukan oleh manusia, wācika sebagai berkata-kata yang keluar dari mulut seseorang, dan manacika yang berhubungan dengan pikiran-pikiran yang dipikirkan oleh manusia. Tri kaya ini yang menyebabkan seseorang dapat jatuh ke dalam neraka, atau pun sebaliknya dapat meningkatkan seseorang menuju ke alam sorga.

Berkenaan dengan penelitian ini teks Agastya Parwa mengacu pada naskah Agastya Parwa yang dijadikan sebagai teks. Teks yang diacu dalam penelitian ini adalah dialog antara Bhagawān Agastya dengan putranya yang bernama Sang Dådhasyu. Teks Agastya Parwa yang dijadikan objek penelitian ini khususnya menyangkut inspirasi dalam mewujudkan profesionalitas kerja sesuai dengan swadharma. Teks yang dijadikan sumber data dalam penelitian ini diambil yang sesuai dengan fokus penelitian dan selanjutnya dianalisis secara kontekstual. Proses analisis secara kontekstual dalam penelitian ini juga dilanjutkan untuk memberikan model penerapan dalam kehidupan masyarakat Hindu. Berikut ini dikutip sejumlah ajaran yang berkaitan dengan fokus penelitian, namun tidak 
diberikan penomoran karena memang dalam teks sumbernya tidak berisi pengurutan sesuai nomor.

"svadharma sādhanāt kuryād

brāhmaóah kṣatriyah punạ

vaiśyah śro yathākām

sthitam etaj jagattrayam;

Kalinanya:mañke śila nika sañ catur waróa ṅuni.

Caturwarna ñaranya: brāhmaóa, kșatriya, waiśya,

śudra. kunañ ikan ikaó caódāla mwañ domba kapasuk

in śudra ika, tuhun kanistha nin śudra naranya.

kunan் ikan் mallecha kahen san்kè caturwaróa ika."

artinya:

Tingkah laku sang catur waróa dahulu sebagai berikut. Catur waróa, yaitu Brāhmaóa, kșatriya, Waiśya, dan Śudra. Caódāla dan domba tergolong śudra, namun śudrawaróa yang paling rendah. Adapun mlecca berada di luar catur waróa itu.

Berdasarkan teks di atas, Bhagawān Agastya menyampaikan tingkah laku sang catur waróa pada masa lalu. Dalam teks tersebut yang disebut dengan sang catur waróa adalah brāhmaóa, kșatriya, waiśya, dan śudra. Di samping keberadaan empat golongan warna tersebut ada lagi dikatakan dengan sebutan caódāla dan domba. Keduanya dikelompokkan dalam golongan śudra. Sebagaimana disebutkan dalam teks śudrawaróa merupakan golongan yang paling rendah. Bhagawān Agastya juga menyebutkan adanya mlecca yakni mereka yang posisinya berada di luar catur waróa itu.

Berkaitan dengan penjelasan Bhagawān Agastya mengenai keberadaan dan perilaku sang brāhmaóa, meliau melanjutkan penjelasannya seperti dipetik dalam kutipan berikut ini:

\footnotetext{
“ Kunañulah saì brāhmaóa man்ke ulahakĕna nira yatanyan nirwighna $\dot{n}$ bhuana : agĕlěma ta sira magawe paňcakrama lokikācāra, yan sĕdaì sira tamolah rin rāja. nuniweh yan pinaka purohita de saì prabhu, agĕlěma ta sirāmujā,matrisandya, toyasnāna, bhasmasnāna, mantrasnāna; mañkanānakĕn udakāňjali ri Sà̀ Hyà் Śiwāditya. Yatika gawayakěna nira, tatar panaódan dodot wirupa-wirupa naranya carik emĕl-, śudhā radina paripuróa juga tikan் dodot saóda nira, tatar pañĕnjak-ěnjaka; tatar parā ri umah niñ omah, kewālā yogā juga sira. Tatar
} 


\section{SOPHIA DHARMA, Vol 4, No. 1, Mei 2021}

bandha-paribandhā ta sira, inuniweh byasanābyasanā ñaranya tripana, dyuttādi, ika tan gawayakĕna de saì brāhmana- tan parā wyāmoha yan wuwus magawe lokikācāra(lokikācāra) inaran ira pujā,yajn̄ā- yatika tan Tulayĕn ira. Tan tirwa ulah nin tiga sira. Tiga naranya : kșatriya, weśya śudra; kewala marahana juga sira ri saó tiga warna. Apan rwa kewala gawayakěna de saó brāhmaóa. Rwa ñaranya: Kriyārcana; kryāwidhi yoga, kunaì śsamaókana Tulayĕn sà̃ brāhmaóa. Yāwat man்kana śila nira san dwija enak tikan rat, swastha tikan bhuana. Apan atěguh san brāhmaóa ri swadharma nira, Tinut ri těguh nin bhuana."

Artinya:

Perilaku Sang Brāhmaóa yang harus dilaksanakannya agar dunia ini bebas dari bahaya adalah beliau tekun mengerjakan paňcakarmalokikācāra. Apabila beliau tinggal bersama-sama dengan sang raja, lebih-lebih beliau bila dijadika purohita oleh sang prabhu, beliau tekun memuja, melakukan tri sandhya, toyasnāna, bhasmasnāna, mantrasnāna; pula melaksanakan udakaňjali pada Sang Hyang Śiwāditya. Itulah hendak dikejar oleh beliau, tidak memakai dodot yang wirupa ialah coreng-moreng dan kotor. Dodot yang dipakainya bersih, bagus, dan utuh, tidak boleh ada bekas injakan. Tidak boleh masuk rumah orang yang bersuami istri, beliau hanya beryoga. Beliau tidak boleh menyakiti, lebih-lebih melaksanakan kebiasan-kebiasaan buruk. Kebiasaan-kebiasaan buruk seperti melakukan permainan seperti berjudi dan lain-lainnya. Itulah tidak boleh dilakukan oleh sang brahmana, tidak sampai kehilangan kesadaran ketika beliau membicarakan dan melaksanakan lokikācāra(lokikācāra)ialah puja atau pemujaan dan yajna - itulah yang beliau tidak lakukan dan harus tidak meniru tingkah lakunya tiga waróa yaitu Kșatriya, Waiśya, dan Śudra. Beliau hanya mengajarkan saja sang tiga waróa itu. Karena hanya dua hal saja yang dikerjakan oleh sang brāhmaóa yaitu: kriyārcana; dan kriyāwidhi yoga. Itulah yang hendaknya dikerjakan oleh sang brāhmaóa. Bila sudah demikian perilaku sang brāhmaóa maka dunia akan sejahtera dan tenteram karena sang brāhmaóna teguh memegang swadharmanya, yang akan disusul oleh kuatnya dunia.

Bersadarkan kutipan teks di atas Agastya Parwa Perilaku menyampaikan bahwa sang brāhmaóa memiliki kewajiban untuk membebaskan dunia dari dari keadaan bahaya. Untuk membebaskan dunia dari bahaya perilaku yang harus dilaksanakannya sang brāhmaóa adalah beliau tekun mengerjakan paňcakarmalokikācāra. Sebagaimana disampaikan oleh Bhagawān Agastya dalam teks, bahwa apabila sang brāhmaóa tinggal 
bersama-sama dengan sang raja, lebih-lebih beliau bila dijadika purohita oleh sang prabhu, maka sang brāhmaóa hendaknya tekun memuja, melakukan tri sandhya, toyasnāna, bhasmasnāna, mantrasnāna; pula melaksanakan udakaňjali pada Sang Hyang Śiwāditya. Perilaku-perilaku tersebut hendaknya dilakukan oleh sang brāhmaóa dalam upaya untuk membebaskan dunia dari keadaan bahaya.

Dalam melakukan kewajibannya, sesuai dengan teks di atas sang brāhmaóa tidak memakai dodot yang wirupa ialah coreng-moreng dan kotor. Dodot yang dipakainya bersih, bagus, dan utuh, tidak boleh ada bekas injakan. Dalam konteks ini sang brāhmaóa sepatutnya menggunakan dodot yang selain memiliki kesucian, juga hendaknya menunjukkan sifat-sifat fisik yang berkualitas seperti kondisinya bersih, bentuknya bagus, keberadaannya masih utuh, dan tidak diperbolehkan menggunakan dodot yang telah pernah diinjak. Penggunaan dodot yang dipersyaratkan seperti itu supaya sang brāhmaóa dalam melaksanakan kewajiban beliau tetap mampu mempertahankan kesucian dan kewibawaan.

Berkaitan dengan aspek etika, sang brāhmaóa tidak diperbolehkan memasuki rumah orang yang bersuami istri, beliau hanya beryoga. Dalam konteks ini sang brāhmaóa dalam upaya untuk selalu menjaga kesuciannya, beliau hendaknya menjauhi hal-hal yang berhubungan dengan kondisi grhasta seperti masuk ke dalam rumah pasangan suami istri. Sang brāhmaóa juga tidak dibenarkan untuk melakukan tindakan yang bersifat menyakiti, demikian juga melaksanakan kebiasan-kebiasaan buruk sesuai dengan teks di atas tidak dibenarkan. Kebiasaan-kebiasaan buruk yang dipantangkan sang brāhmaóa yakni melakukan permainan seperti berjudi dan lain-lainnya. Kebiasaan-kebiasaan buruk tersebut akan mempengaruhi kesucian diri sang brāhmaóa sehingga harus dihindari.

Dalam teks di atas Bhagawān Agastya menyampaikan bahwa sang brāhmaóa agar tidak sampai kehilangan kesadaran ketika beliau membicarakan dan melaksanakan lokikācāra - (lokikācāra) yaitu puja atau pemujaan dan yajna - itulah yang beliau tidak lakukan dan harus tidak meniru tingkah lakunya tiga waróa yaitu Kșatriya, Waiśya, dan Śudra. Ajaran yang disampaikan oleh Bhagawān Agastya secara implisit mengajarkan bahwa sang brāhmaóa memiliki tingkatan hidup yang berbeda dengan ketiga warna lainnya. Untuk mempertahankan kedudukannya itu, sang brāhmaóa seyogyanya tidak meniru kelakuan ketiga warna tersebut. Sang brāhmaóa hendaknya berkewajiban hanya mengajarkan saja sang tiga waróa itu yaitu kșatriya, waiśya, dan śudra. 


\section{SOPHIA DHARMA, Vol 4, No. 1, Mei 2021}

Berkenaan dengan kewajiban yang hendaknya dilaksanakan oleh sang brāhmaóa sebagaimana disebutkan dalam teks di atas ada dua hal terpenting yang dikerjakan. Pertama, sang brāhmaóa berkewajiban melakukan kriyārcana. Kedua, sang brāhmaóa juga berkewajiban melakukan kriyāwidhi yoga. Kedua kewajiban yang disebutkan dalam teks Agastya Parwa hendaknya dikerjakan oleh sang brāhmaóa. Ditambahkan pula bahwa jika kedua kewajiban itu telah dilaksanakan oleh sang brāhmaóa maka dunia akan sejahtera dan tenteram. Hal tersebut ditegaskan karena didasari oleh alasan bahwa jika sang brāhmaóna teguh dalam memegang swadharma-nya, maka yang akan terjadi adalah kondisi dunia yang kuat.

Teks di atas mendeskripsikan kewajiban-kewajiban yang patut dilaksanakan oleh sang brāhmaóa dalam rangka menopang kekuatan dunia. Dalam hal ini teks tersebut bermakna bahwa sang brāhmaóa ditinjau dari segi kedudukannya memiliki posisi tertinggi dibandingkan dengan tiga warna yang lainnya. Dalam kitab suci Veda yakni pada Yajur Veda XXXI. 11 disebutkan bahwa brahmana dianalogikan sebagai mulut-NYA Tuhan. Titib (1998: 390) menganalogikan kehidupan manusia dalam komunitasnya sebagai makhluk kosmos yang secara anatomis menggambarkan pengelompokkan manusia atas dasar profesi (varna) yang digelutinya. Brahmana (para pemikir) dianalogikan sebagai mulut/ kepalanya. Sejalan dengan hal tersebut sang brāhmaóa diasumsikan sebagai golongan tertinggi dan diyakini memiliki kemampuan untuk mengatur golongan yang lainnya. Karena itu teks Agastya Parwa menyatakan bahwa sang brāhmaóa merupakan simbol penopang kekuatan dunia apabila beliau mampu memegang swadharma-nya.

Setelah mendeskripsikan kewajiban yang seyogyanya dilaksanakan oleh sang brāhmaóa dalam upaya menjaga ketertiban dunia, maka pada bagian selanjutnya Bhagawān Agastya menguraikan tugas dan kewajiban warna berikutnya yakni warna kșatriya atau yang dalam teks Agastya Parwa disebut sebagai sang kṣatriya. Uraian tentang sang kșatriya yang diajarkan oleh Bhagawān Agastya kepada putra beliau yakni Sang Dådhasyu seperti dikutip pada kutipan berikut ini.

"maìkana san kșatriya, nihan ulaha nira: masiha

rin rat umaritrāóà $\dot{n}$ hina dina, humilañakèna

kalènkanìn bhuana, śurā ta sira rin samara,

danāśurā ta sira, umintuhwa ri nwarah Sà் Hyà் 
āgama, bhaktya ta sira rï̀ saì brāhmana, nahan ulaha nira san kșatriya."

Artinya:

Demikian pula sang kșatriya. Inilah yang harus dilakukan yaitu kasih sayang kepada dunia, melindungi orang yang lemah, menghilangkan keburukan dunia, harus gagah berani di medan perang, harus berani menjadi pahlawan dan berderma, mematuhi ajaran-ajaran agama, dan bhakti kepada sang brāhmaóa. Demikianlah hendaknya perilaku sang kșatriya.

Berdasarkan teks di atas Bhagawān Agastya mengajarkan putranya Sang Dådhasyu tentang kewajiban yang harus dilakukan oleh sang kșatriya. Kewajiban yang pertama yang harus dijalankan oleh sang kșatriya sesuai dengan teks di atas adalah mencurahkan kasih sayang kepada dunia. Dalam hal ini dimaksudkan bahwa sang kșatriya harus menerapkan rasa kasih sayang kepada seisi dunia khususnya kepada makhluk hidup.

Kewajiban yang kedua yang harus dilaksanakan oleh sang kșatriya sesuai dengan teks di atas adalah melindungi orang yang lemah. Dalam konteks ini sang kṣatriya dalam rangka ikut menegakkan keharmonisan dunia harus memiliki kepekaan khususnya terhadap orang-orang yang lemah. Sang kșatriya harus berani membela yang lemah sesuai dengan swadharma-nya. Hal ini mengimplikasikan bahwa sang kșatriya tidak harus tunduk pada kekuasaan, namun diharapkan mampu menghormati kebenaran kendati letak kebenaran itu pada orang-orang yang lemah, pada mereka yang tidak berdaya menghadapi kekuasaan.

Ketiga, sang kșatriya hendaknya mampu menghilangkan keburukan dunia. Dalam konteks ini sang kșatriya diharapkan mampu untuk melenyapkan permasalahanpermasalahan yang menimbulkan ekses negatif bagi kehidupan umat manusia di muka bumi ini. Permasalahan-permasalahan yang menimbulkan keburukan dunia itu banyak macamnya seperti kemiskinan, kebodohan, kekacauan, serta masalah-masalah lainny yang bertendensi menurunkan kualitas kehidupan manusia dan masyarakat. Dalam konteks kehidupan masyarakat modern, sang kșatriya adalah mereka yang berada pada posisi pemegang kekuasaan baik kekuasaan yang kasat mata seperti dalam sistem pemerintahan maupun yang tidak kasat mata yakni kekuasaan simbolik. 


\section{SOPHIA DHARMA, Vol 4, No. 1, Mei 2021}

Keempat, sang kșatriya harus gagah berani di medan perang. Dalam konteks ini sang kșatriya memiliki kewajiban sebagai pelindung kebenaran khususnya di saat-saat terjadi konflik. Karena itu, sebagaimana diamanatkan dalam teks di atas bahwa sang kșatriya harus berani menunjukkan sikap-sikap yang gagah berani di medan pertempuran. Sang kșatriya tidak boleh mengundurkan diri dari medan pertempuran, karena itu merupakan tindakan yang tidak perpuji bagi sang kṣatriya.

Kelima, sang kṣatriya harus berani menjadi pahlawan dan berderma. Kewajiban ini masih erat kaitannya dengan kewajiban keempat yakni melalui keberanian yang tumbuh dari diri sang kṣatriya akan mampu menumbuhkan sikap-sikap kepahlawanan. Sikap-sikap kepahlawanan bagi sang kșatriya salah satunya adalah berani membela kebenaran dimanapun posisinya. Selain itu, sang kșatriya juga harus menunjukkan sikap yang dermawan. Dalam hal ini sang kșatriya harus mampu menumbuhkan sikap-sikap yang berani mengorbankan sebagian miliknya untuk diberikan kepada orang lain yang memebutuhkan.

Keenam, dalam kaitannya dengan aspek religius sebagaimana diajarkan oleh Bhagawān Agastya bahwa sang kṣatriya hendaknya mematuhi ajaran-ajaran agama. Dalam konteks ini sang kṣatriya kendati memiliki tugas utama mencurahkan kasih sayang kepada dunia dengan sikap-sikap keberanian dan kepahlawanannnya sebagaimana disebutkan di atas, juga diharapkan mematuhi ajaran-ajaran yang diamanatkan dalam kitab suci. Bahkan dalam melaksanakan ajaran agama sang kșatriya hendaknya menjalin hubungan dengan sang brāhmaóa. Dalam masa pemerintahan kerajaan di masa lalu hubungan antara sang kṣatriya dengan sang brāhmaóa sangat erat. Bahkan di lingkungan kerajaan ditempatkan sang brāhmaóa sebagai purohita kerajaan.

Ketujuh, berkenaan dengan upaya menjalin hubungan antara sang kșatriya dengan sang brāhmaóa sebagaimana disebutkan dalam teks di atas sang kṣatriya hendaknya bhakti kepada sang brāhmaóa. Teks tersebut secara implisit menyiratkan bahwa sang kṣatriya dalam melakukan kewajiban-kewajiban sucinya dalam rangka mewujudkan keharmonisan hidup di dunia harus mewujudkan rasa bhakti kepada sang brāhmaóa. Teks di atas mengamanatkan bahwa harus terbangun jalinan yang erat antara sang kșatriya dengan sang brāhmaóa dalam rangka mewujudkan keharmonisan baik dalam aras horizontal yakni 


\section{Gusti Komang Kembarawan-Meniti Teks Ajaran Hindu sebagai Inspirasi Mewujudkan Profesionalitas Kerja sesuai Guna dan Karma}

hubungan kemasyarakatan maupun hubungan vertikal berupa hubungan dengan aspek transenden yaitu Ida Sang hyang Widhi Waça beserta segenap manifestasinya.

Berdasarkan pemaparan di atas, dapat diambil benang merahnya bahwa ada sejumlah kewajiban yang harus dijalankan oleh sang kṣatriya dalam rangka mewujudkan ketertiban dan keharmonisan dunia. Kewajiban-kewajiban tersebut merupakan ramburambu yang harus dipatuhi oleh sang kṣatriya untuk membangun tatanan kehidupan sosial yang ideal di dunia ini. Sesuai dengan teks di atas sang kṣatriya hendaknya melakukan bhakti kepada sang brāhmaóa, mngimplikasikan bahwa dari segi kedudukannya yang lebih rendah dibandingkan dengan kedudukan sang brāhmaóa. Namun, dalam realitasnya wujud bhakti tersebut dapat diwujudkan dengan menghormati dan menjalin hubungan yang erat antara sang kṣatriya dengan sang brāhmaóa.

Ajaran berikutnya yang disampaikan oleh Bhagawān Agastya kepada putranya yaitu Sang Dådhasyu adalah berkaitan dengan kewajiban-kewajiban yang harus dijalankan oleh warna vaiśya yang dalam teks Agastya Parwa disebut dengan sang vaiśya. Adapun kewajiban-kewajiban yang harus dilaksanakan oleh sang vaiśya dalam naskah Agastya Parwa adalah seperti dalam kutipan berikut ini.

"Kunà் ulahanin waiśya: yatnā ta sira ri karaksan San Hyan் Śri. Śri naranya mas maóik rājata wastra dhānyādi mwan stri rahayu, ṅguniweh karakșan in

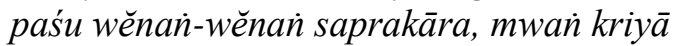
sambyawahāra. Yatnā saì waiśya ṅaranya, tan parachidrā rin para; tan panirwa ulah Sàn Kṣtriya, kewalya dharmanin Waiśya juga gayawakěna nira. Ulah pwa sira mañarjana, magayawakĕna ta sira kāyika dharma

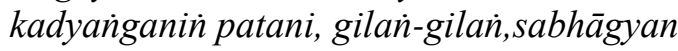
wěnañagawe wihāra śālā, paryañan, kut, patapan,

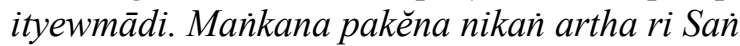
Waśya. Nahan ta ulaha Sañ Waiśya."

Artinya:

Perilaku sang vaiśya adalah harus hati-hati menjaga Sang Hyang Śri. Śri adalah emas, permata, perak, pakaian dan lain-lainnya, serta padipadian. Di samping itu juga wanita-wanita cantik, binatang-binatang ternak, dan sebagainya, dan usaha dalam perdagangan sang waiśya akan dikatakan hati-hati bila ia tidak menghianati orang lain, tidak meniru perilaku sang kșatriya, hanya dharma sebagai waiśya saja yang 
dikerjakannya. Kegiatannya ialah berusaha melakukan kāyika dharma seperti membuat tempat duduk, rumah kecil untuk peristirahatan. Di samping itu dapat membuat wihara, rumah, tempat pemujaan, tempat tinggal pendeta, pertapaan, dan lain-lainnya. Untuk tujuan itulah harta yang dimiliki oleh waiśya. Demikian hendaknya perilaku waiśya.

Berdasarkan teks di atas Bhagawān Agastya menyampaikan ajaran yang berkaitan dengan kewajiban-kewajiban yang harus dilaksanakan oleh sang vaiśya. Pertama, perilaku yang harus dilaksanakan oleh sang vaiśya adalah harus hati-hati menjaga Sang Hyang Śri. Dalam realitasnya, Sang Hyang Śri diwujudkan dengan bentuk-bentuk simbolik seperti emas, permata, perak, pakaian dan lain-lainnya, serta padi-padian. Bentuk-bentuk simbolik tersebut sebagai manifestasi Sang Hyang Śri dilandasi oleh filosofi bahwa keberadaan Sang Hyang Śri di dunia ini sebagai sumber kemakmuran dan kesejahteraan. Bertalian dengan hal tersebut bentuk-bentuk simbolik seperti emas, permata, perak, pakaian dan lainlainnya, serta padi-padian sebagai indikator kemakmuran dan kesejahteraan di alam duniawi. Karena dimana terdapat unsur-unsur tersebut maka disanalah letak kemakmuran dan kesejahteraan duniawi.

Di samping itu teks di atas juga menyebutkan bahwa wanita-wanita cantik, binatang-binatang ternak, dan sebagainya, dikategorikan sebagai simbol-simbol yang erat pertaliannya dengan Sang Hyang Śri. Hal tersebut dilandasi oleh pemikiran bahwa elemen-elemen dunia seperti wanita-wanita cantik, binatang-binatang ternak, dan sebagainya sebagai wahana untuk mewujudkan kemakmuran dan kesejahteraan dunia sebagaimana personifikasikan dengan dewi yang cantik yakni Sang Hyang Śri. Dalam teks di atas juga diungkapkan bahwa usaha dalam perdagangan merupakan profesi yang erat pertaliannya dengan sang waiśya. Dalam melaksanakan kewajiban-kewajibannya, sang waiśya diharapkan bersikap hati-hati bila ia tidak menghianati orang lain.

Sang waiśya ssuai dengan yang secara tersurat dalam teks di atas, diharapkan tidak meniru perilaku sang kșatriya. Dalam konteks ini sang waiśya harus tetap berpegang teguh pada kewajiban-kewajiban yang harus dilaksanakannya. Sang waiśya diharapkan tidak meniru perilaku sang kșatriya, hanya dharma sebagai waiśya saja yang dikerjakannya. Teks tersebut mengimplikasikan bahwa seseorang harus ditempatkan sesuai dengan profesionalitasnya. Karena dengan demikian seseorang akan dapat melaksanakan 
kewajiban-kewajiban yang melekat pada dirinya lebih sempurna. Jika sang waiśya menguasai aspek-aspek kehidupan yang berhubungan dengan upaya membangun kesejahteraan dan kemakmuran dunia, maka tugas dan kewajiban yang melekat pada sang waiśya berkaitan dengan mata pencaharian sebagai pedagang, petani, peternakan, dan sejenisnya. Sang waiśya tidak akan profesional jika membidangi hal-hal yang berkaitan dengan keamanan dan kepahlawanan sebagaimana yang melekat pada kewajiban sang kșatriya.

Perincian tugas dan kewajiban yang hendaknya dijalankan oleh sang waiśya sebagaimana disebutkan dalam teks di atas adalah kegiatan yang berkaitan dengan usaha untuk melakukan kāyika dharma. Tugas sang waiśya dalam usaha untuk melakukan kāyika dharma seperti membuat tempat duduk, rumah kecil untuk peristirahatan. Di samping itu dapat membuat wihara, rumah, tempat pemujaan, tempat tinggal pendeta, pertapaan, dan lain-lainnya. Untuk tujuan itulah harta yang dimiliki oleh waiśya. Demikian rincian tugas yang hendaknya dilakukan oleh sang waiśya.

Berdasarkan teks di atas, Bhagawān Agastya mengajarkan cara-cara untuk mewujudkan kesejahteraan dan kemakmuran di dunia ini melalui kewajiban-kewajiban yang harus dilaksanakan oleh sang waiśya. Benang merah yang ditemukan dalam teks di atas dalam aspek sosiologis adalah menempatkan sang waiśya sebagai warna ketiga dari catur warna dalam posisinya untuk membangun kesejahteraan sosial. Kewajibankewajiban yang harus dilaksanakan oleh sang waiśya dalam mewujudkan keharmonisan sosial adalah berkaitan dengan usaha untuk melakukan kāyika dharma. Dengan memahami dan melaksanakan kāyika dharma mengimplikasikan harapan-harapan untuk membangun ketertiban sosial dalam bidang pemenuhan kebutuhan-kebutuhan yang berhubungan dengan peningkatan kualitas hidup di dunia ini.

Berkaitan dengan membahas kewajiban-kewajiban yang hendaknya dijalankan oleh warna śudra yang dalam teks disebut sebagai sang śudra, Bhagawān Agastya mengajarkan kepada putranya yaitu Sang Dådhasyu ada sejumlah kewajiban yang harus dilaksanakan oleh sang śudra dalam naskah Agastya Parwa adalah seperti dalam kutipan berikut ini.

“Kunañ ulaha Sà் Śudra ikan் yogya 


\title{
SOPHIA DHARMA, Vol 4, No. 1, Mei 2021
}

\author{
Lakwakĕnanya: yatnaha, ya tanpānukula, haywa \\ tan matěguh ri śāsana, tututa ri pakon san trijanma, \\ haywa umalan manahnya, apan ikaì śudrajanma \\ kakawaśa deni san trijanma, apan huwus tinitah \\ de Bhatțāra ikan hastapada de sañ trijanma ri \\ dharmasādhana. San Waiśya matěguh ri \\ swadharma nira. Ikan் Śudra matěguh i dharmanya."
}

Artinya:

Perilaku sang śudra yang patut dilakukan ialah berhati-hati, ia harus patuh, harus teguh pada śāsana, hendaknya mengikuti perintah sang tri janma, jangan menghalang-halangi kehendaknya sebab sang śudra janma dikuasai oleh sang tri janma, serta telah ditentukan oleh Bhațāra sebagai kaki tangan sang tri janma dalam pelaksanaan dharma. Waiśya berpegang teguh pada swadharma-nya. Śudra pun berpegang teguh pada swadharma-nya.

Bertolak dari teks di atas, Bhagawān Agastya mengajarkan kepada putranya Sang Dådhasyu tentang kewajiban-kewajiban yang hendaknya dilakukan oleh warna śudra atau sang śudra yang pertama dikatakan bahwa sang śudra harus menunjukkan sikap kehatihatian. Sikap tersebut harus ditubuhkan dan dipupuk karena kedudukan sang śudra sebagai kaki tangan ketiga golongan di atasnya yakni sang tri janma. Dalam konteks ini secara implisit kedudukan sang śudra sebagai pembantu atau melayani ketiga warna di atas. Kedudukan sebagai pelayan yang bertugas melayani sang tri janma, hendaknya dilakoni dengan penuh kehati-hatian.

Kewajiban kedua yang harus dilakukan oleh sang śudra sebagaimana diamanatkan dalam teks di atas adalah sikap kepatuhan. Sebagaimana telah disebutkan pada bagian atas bahwa kedudukan sang śudra sebagai pelayan sang tri janma maka seyogyanya sang śudra mampu menunjukkan dedikasi yang tinggi kepada mereka yang dilayaninya. Sikap yang patuh kepada sang tri janma yang disertai dengan dedikasi yang tinggi memberikan jalan bagi munculnya interaksi yang harmonis antara sang śudra dengan ketiga golongan yang berada di atasnya.

Kewajiban ketiga yang harus dilaksanakan oleh sang śudra adalah keteguhan dalam memegang śāsana. Śāsana dalam konteks ini adalah tingkah laku yang baik dan benar sesuai dengan fungsionalisasi yang dijalankan. Kewajiban keempat yang harus dilaksanakan oleh sang śudra adalah selalu mengikuti perintah sang tri janma. Mengingat 
sang śudra memiliki kedudukan sebagai pelayan sang tri janma sudah menjadi kewajiban bagi sang śudra untuk selalu melaksanakan perintah-perintah yang diperintahkan oleh sang tri janma. Kewajiban ini juga dilakukan dalam rangka untuk menjaga hubungan yang harmonis antara sang śudra dengan ketiga golongan di atasnya.

Kewajiban kelima yang harus dijalankan oleh sang śudra adalah tidak boleh menghalang-halangi kehendak sang tri janma. Apapun bentuk perintah yang diberikan oleh ketiga golongan di atasnya (sang tri janma) harus dilaksanakan dengan pebuh tanggung jawab oleh sang śudra. Jika sang śudra sampai menghalang-halangi kehendak sang tri janma merupakan pelanggaran terhadap śāsana yang telah ditetapkan kepada śāsana . Fenomena tersebut sebagaimana telah digariskan dalam teks sebelumnya bahwa sang śudra janma dikuasai oleh sang tri janma. Kewajiban yang melekat pada diri śāsana telah ditentukan oleh Bhațāra bahwa keberadaan śāsana sebagai kaki tangan sang tri janma dalam pelaksanaan dharma.

Kewajiban berikutnya yang hendaknya dijalankan oleh śāsana adalah harus selalu memegang teguh swadharma-nya. Dalam konteks ini sang waiśya berpegang teguh pada swadharma-nya yakni kewajiban-kewajiban yang melekat pada kedudukannya demikian pula halnya dengan sang śudra, mereka juga hendaknya berpegang teguh pada swadharmanya, khususnya dalam memberikan pelayanan kepada sang tri janma.

\section{Profesionalitas menurut Ajaran Veda}

Kitab suci Yajur Veda dalam melihat keberadaan pembagian masyarakat berdaraskan catur warna yakni empat pembagian masyarakat berdasarkan profesionalisasinya dapat dikatakan bahwa varna dharma sebagaimana yang secara implisit diamanatkan dalam mantra baik dalam kitab suci Yajur Veda maupun yang terdapat dalam teks Agastya Parwa menjadi kekuatan simbolik yang memberikan inspirasi bagi kehidupan sosial dalam menciptakan keharmonisan secarasistemik.

\footnotetext{
"Brāhmano-asya mukham āsīd, bāhuu rājanyah krtah. ürü tadasya yad vaiśyah, padbhyāim śudro ajāyata."
}

Yajur Veda XXXI.11 


\title{
SOPHIA DHARMA, Vol 4, No. 1, Mei 2021
}

\author{
Brahmana adalah mulut-NYA Tuhan Yang Maha Esa, \\ ksatrya lengan-lengan-NYA, vaisya paha-NYA dan \\ sudra kaki-kaki-NYA (Titib, 1998:390).
}

Sesuai dengan teks mantra di atas, kehidupan sosial dianalogikan seperti anatomi tubuh yang memiliki mulut, memiliki tangan, memiliki perut, serta memiliki kaki. Sesuai dengan kutipan mantra di atas, yang menjadi mulut adalah warna brāhmaóa. Sesuai dengan posisinya, mulut berada pada pada wilayah kepala. Hal ini berarti bahwa brāhmaóa berkedudukan pada bagian utama tubuh. Ini mengindikasikan bahwa brāhmaóa memiliki kedudukan yang paling mulia dibandingkan dengan warna lainnya dalam sistem catur warna. Sebagaimana disebutkan dalam teks Agastya Parwa bahwa brāhmaóa harus tidak meniru tingkah lakunya tiga waróa yaitu Kṣatriya, Waiśya, dan Śudra. Beliau hanya mengajarkan saja sang tiga waróa itu. Karena hanya dua hal saja yang dikerjakan oleh sang brāhmaóa yaitu: kriyārcana; dan kriyāwidhi yoga. Itulah yang hendaknya dikerjakan oleh sang brāhmaóa. Bila sudah demikian perilaku sang brāhmaóa maka dunia akan sejahtera dan tenteram karena sang brāhmaóna teguh memegang swadharmanya, yang akan disusul oleh kuatnya dunia. Berdasarkan kutipan di atas dapat dikatakan bahwa warna brāhmaóa memiliki kedudukan yang lebih tinggi dari warna yang lainnya.

Warna kedua dalam kutipan kitab suci Yajur Weda adalah warna kșatriya. Analogi bentuk tubuh yang melekat pada warna kṣatriya adalah sebagai lengan-lengan-NYA. Dalam hal ini dimaksudkan bahwa warna kṣatriya memiliki kekuatan untuk menjaga ketentraman dunia sosial karena melihat fungsi dari lengan adalah sebagai alat tubuh yang paling berguna untuk melakukan kerja dan untuk mempertahankan diri. Dalam teks Agastya Parwa yang telah dikutip pada bagian sebelumnya bahwa warna kṣatriya hendaknya mampu mewujudkan kasih sayang kepada dunia, melindungi orang yang lemah, menghilangkan keburukan dunia, harus gagah berani di medan perang, harus berani menjadi pahlawan dan berderma, mematuhi ajaran-ajaran agama, dan bhakti kepada sang brāhmaóa. Sinergisme antara teks Agastya Parwa dengan kitab suci Yajur Veda mengindikasikan bahwa ajaran catur warna telah memproyeksikan tatanan kehidupan sosial dari masa penyusunan kitab suci Veda sampai pada zaman modern masih relevan. 
Berikut ini juga terdapat mantra dari kitab suci Yajur Veda yang menekankan ajaran untuk membangun suatu keharmonisan antara varna khususnya antara warna brahmana dengan warna ksatriya seperti dikutip berikut ini.

"Yatra brahma ca ksatram ca, Samyancau caratah saha.

Tam lokam punyam prajnesam, Yatra dewah sahagnina."

\section{Yajur Veda XX.25}

Di negara itu seharusnya diperlakukan warga negaranya sebaik mungkin, disana para brahmana dan para ksatriya hidup di dalam keserasian dan orang-orang yang terpelajar melaksanakan persembahan /pengorbanan (Titib, 1998: 391).

Berdasarkan mantra di atas secara eksplisit menyuratkan bahwa harus dibangun hubungan yang harmonis antara warna khususnya antar warna brahmana dengan warna ksatrya. Mantra tersebut memberikan inspirasi kepada umat bahwa dalam melaksanakan kewajiban suci, varna brahmana dan warna ksatriya hendaknya bisa hidup harmonis. Secara kontekstual konsepsi yang dikemukakan dalam mantra tersebut terbukti benar. Dalam praktik kehidupan beragama terutama dalam masyarakat Hindu di Lombok jika varna brahmana dan varna ksatriya tidak harmonis maka tidak akan pernah diselesaikan kewajiban-kewajiban suci sebagaimana yang diamanatkan di dalam kitab suci Veda.

Hasil wawancara yang dilakukan dengan informan juga menyampaikan bahwa sejak masuknya orang-orang Bali yang beragama Hindu di Pulau Lombok dua warna yakni warna brahmana dan warna ksatriya dalam menata kehidupan sosial saling bekerjasama. Varna ksatriya yang diwakili oleh raja sebagai pemimpin tertinggi pasukan dengan pedanda (pendeta Hindu) yang mewakili brahmana warna sangat dekat hubungannya. Melalui keserasian hjubungan yang dibangun oleh kedua varna tersebut sehingga mampu mencapai puncak keemasan kerajaan di Lombok. Keserasian tersebut hingga kini harus 
dipertahankan karena jika pihak penguasa dengan pendeta tidak bekerja sama maka dapat dipastikan bahwa aktivitas keberagamaan di kalangan masyarakat Hindu tidak akan pernah diterselenggara.

Dalam rangka untuk bisa mewujudkan masyarakat yang makmur diamanatkan supaya ketiga warna yaitu brahmana, ksatriya dan vaisya dapat melaksanakan kewajibannya. Hal tersebut seperti dikutip dalam mantra Yajur Veda seperti berikut ini:

"Ise pinvasvaurje pinvasva,
brahmana pinvasva
brahma dharaya,
ksatram dharaya, visam dharaya"

Yajur Veda XXXVIII. 14

\begin{abstract}
Ya, Tuhan yang Maha Esa, perkuatlah para brahmana, para ksatriya dan para vaisya, supaya mereka menyediakan pengetahuan, kekuatan dan keberlimpahan makanan (Titib, 1998: 392).
\end{abstract}

Ajaran yang terkandung dalam mantra Yajur Veda XXXVIII.14 di atas pada prinsipnya adalah peranan ketiga warna yakni warna brahmana, warna ksatrya, dan warna waisya dalam upaya membangun kesejahteraan sosial. Ketiga warna di atas jika dapat menjalankan fungsionalisasinya masing-masing menjadi penentu dalam mewujudkan masyarakat yang sejahtera baik secara lahiriah dan batiniah. Karena itu, mantra di atas mengamanatkan bahwa harus dilakukan penguatan terhadap ketiga warna tersebut dengan jalan saling mengetahui dan menjalankan fungsionalisasinya. Jika tidak, maka akan terjadi hal yang sebaliknya yakni akan muncul ketidakteraturan sosial.

Sedangkan warna sudra dalam kutipan mantra di atas tidak disebutkan. Hal ini berkaitan dengan fungsionalisasi yang dijalankan oleh warna sudra adalah sebagai pembantu ketiga warna di atasnya. Warna sudra dalam sistem pelapisan sosial sangat erat kaitannya dengan profesi yang digeluti sebagai pekerja yaitu profesi-profesi yang berkenaan dengan membantu memberikan pelayanan khususnya kepada tiga golongan profesi sebelumnya yaitu brahmana, ksatriya dan waisya. Secara esensial keempat warna yang secara profesional merupakan bagian dari stratifikasi sosial dalam masyarakat Hindu satu sama lain sesungguhnya saling melengkapi. Jika satu diantara keempat warna tersebut 
mengingkari kewajibannya maka tidak akan mungkin diwujudkan tujuan agama sebagaimana secara konseptual ingin mewujudkan moksartha jagad hita ya ca iti dharmah yang mengandung arti tujuan agama adalah untuk mewujudkan kebahagiaan dunia dan akhirat.

Sejalan dengan fenomena tersebut di atas, dalam upaya untuk menuju kepada klasifikasi masyarakat berdasarkan tugas-tugas/ kewajiban yang didasarkan atas guna dan karma sebagaimana tersurat dalam kitab suci Veda maupun dalam teks Agastya Parwa juga ditunjang oleh sumber-sumber susastra Hindu lainnya. Berkaitan dengan keberadaan aspek sosiologis, khususnya yang menyangkut pembagian masyarakat dalam kelas-kelas sesuai dengan fungsionalisasinya berupa sistem catur warna kitab bhagavadgita juga secara eksplisit mengandung ajaran tentang catur warna. Sloka Bhagavadgita yang mengajarkan tentang keberadaan catur warna seperti yang tersurat dalam bhagavadgita adhyaya IV sloka 13 seperti dalam kutipan berikut ini.

\section{“ Cāturvarnyam mayā șrsțtam gunakarmavibhāgaśah tasya kartāram api mām viddhy akartāram avyayam", Bhagavadgita IV 13}

Artinya:

Catur warna kuciptakan menurut pembagian dari guna dan karma (sifat dan pekerjaan). Meskipun Aku sebagai penciptanya, ketahuilah Aku, mengatasi gerak dan perobahan (Mantra, 2000: 66-67).

Berdasarkan teks sloka bhagavadgita di atas, ajaran catur warna sebagai ciptaan Ida Sang Hyang Widhi Wasa (Tuhan Yang Maha Esa) melekatkan pembagian masyarakat ke dalam guna dan karma. Berkenaan dengan hal tersebut, Mantra (2000: 66-67) memberikan pengertian tentang warna seperti tersebut di atas adalah menurut pembawaan dan fungsinya. Pembagian menjadi empat adalah berdasarkan kewajiban. Orang-orang yang mengabdi sebesar mungkin menurut pembawaannya. Disini ia dapat melaksanakan tugasnya dengan dilandasi rasa cinta dan keikhlasan. 


\section{SOPHIA DHARMA, Vol 4, No. 1, Mei 2021}

Dalam perspektif yang lain, sebagaimana dilihat oleh Wiana (2006: 8) bahwa konsepsi sistem sosial dalam ajaran catur varna kalau dihubungkan dengan fakta sosial dalam wujud catur wangsa atau sistem kasta sangat bertolak belakang. Dalam hal ini berarti bahwa realita ajaran catur varna sangat jauh dari konsepsinya. Hal ini dilihat oleh Wiana sebagai bagian yang tidak terpisahkan dari sistem relegi yang memberikan pengaruh yang sangat besar pada wujud dan gerak sistem sistem sosial dan sistem budaya lainnya.

Berdasarkan analisis di atas dapat ditarik sebuah benang merah yang berkaitan dengan aspek sosiologis yang terdapat dalam teks Agastya Parwa dengan kitab suci Veda beserta susastra sucinya bahwa aspek sosiologis yang terkandung dalam teks Agastya Parwa, yakni berupa ajaran tentang pembagian masyarakat atas dasar fungsionalisasinya yang disebut catur warna memiliki kesamaan dengan kitab suci Veda dan susastra sucinya seperti bhagavadgita. Terdapatnya kesamaan ajaran sebagaimana telah dideskripsikan di atas mengindikasikan bahwa teks Agastya Parwa yang mengandung aspek sosiologis memiliki rujukan pada kitab suci Veda. Hal tersebut juga menyiratkan makna bahwa ajaran tentang pembagian masyarakat atas dasar fungsionalisasinya dalam teks Agastya Parwa masih bersifat murni. Dalam konteks ini dimaksudkan bahwa ajaran dalam teks Agastya Parwa belum menunjukkan adanya pembiasan dari sumber aslinya yakni kitab suci Veda.

\section{Kesimpulan}

Berdasarkan pembahasan hasil penelitian di atas dapat disimpulkan beberapa hal sebagai berikut. Pertama, benih-benih ajaran yang mengandung inspirasi profesionalisme kerja dalam teks Agastya Parwa disajikan dalam bentuk dialog yang pada intinya mengemukakan bahwa profesionalisme kerja diinspirasikan melalui pengelompokkan masyarakat berdasarkan atas catur warna. Ajaran yang terkandung dalam Agastya Parwa dapat digunakan sebagai wahana untuk menentukan bakat-bakat seseorang di dalam mengambil profesi yang sesuai. Keempat penggolongan masyarakat berdasarkan catur warna dalam teks kitab Agastya Parwa sudah ditentukan bidang-bidang yang harus ditekuni oleh setiap individu berdasarkan bidang keahlian yang digelutinya. Mereka yang sudah melaksanakan kerja sesuai dengan yang diajarkan dalam teks Agastya Parwa berpeluang untuk mewujudkan profesionalisme kerja sesuai dengan yang diharapkan. 
Kedua, inspirasi dalam membangun profesionalisme kerja yang terkandung dalam ajaran teks Agastya Parwa memiliki keselarasan dengan ajaran kitab suci Weda dan Bhagawadgita, terutama dalam menentukan profesionalisme yang berdasarkan atas guna dan karma. Ajaran yang menyangkut guna dan karma menjadi inspirasi dalam menentukan profesi yang akan dijalankan sesuai dengan bakat-bakat untuk menghasilkan kinerja yang berkualitas. Setiap individu yang menjalankan pekerjaan sesuai dengan guna dan karma yang dimiliki cenderung akan menghasilkan hasil kerja yang berkualitas. Berkaitan dengan itu, kualitas kerja yang dilaksanakan dikategorikan sebagai kinerja yang professional dan berkualitas.

\section{Daftar Pustaka}

Adnan, Habib. 1999. Agama Masyarakat dan Reformasi Kehidupan. Denpasar: BP Amin, A.d, dkk. 1977. Monografi Daerah Nusa Tenggara Barat. Jakarta:Depdikbud Bakker, J.W.M. 1984. Filsafat Kebudayaan: Sebuah Pengantar. Yogyakarta: Kanisius Budharta, Ida Bagus Gde. 1990. Pertentangan Etnis di Lombok 1891-1942. Yogyakarta: Tesis Pascasarjana UGM

Danim, Sudarwan. 2002. Menjadi Peneliti Kualitatif. Bandung: Pustaka Setia

Dharmayuda, S. I. M. 1995. Kebudayaan Bali: Pra-Hindu, Masa Hindu dan Pasca Hindu. Denpasar: Kayumas Agung

Dillistone, F.W. 2002. Daya Kekuatan Simbol (The Power of Symbols), Yogyakarta: Kanisius

Dwipayana, A.A.G.N. Ari. 2001. Kelas dan Kasta, Pergulatan kelas Menengah Bali. Yogyakarta: Lapera Pustaka Utama 2004. “Geneologi Politik: Desa Adat Bali dan Ruang Demokrasi”. dalam buku Bali Menuju Jagaditha: Aneka Perspektif. Editor I Nyoman Darma Putra. Denpasar: Pustaka Bali Post

Garna, Judistira K. 1992. Teori-Teori Perubahan Sosial. Bandung: PPs-Universitas Padjadjaran 


\section{SOPHIA DHARMA, Vol 4, No. 1, Mei 2021}

Geertz, Clifford. 2001. "Agama Sebagai Sistem Kebudayaan”. dalam buku Dekontruksi Kebenaran Kritik Tujuh Teori Agama. Terjemahan Inyiak Ridwan Muzir, M. Syukri. Yogyakarta: IRCiSoD

......, 1992, Tafsir Kebudayaan. Terjemahan Fransisco Budi Hardiman. Yogyakarta: Kanisius

Gie, The Liang. 2004. Pengantar Filsafat Ilmu. Yogyakarta: Liberty

Jirnaya, I Ketut dkk. 1992. Aspek Sosiologi Sastra Gegurutan Tamtam. Denpasar: Laporan Penelitian Unud.

Kartini Kartono. 1990. Pengantar Metodologi Riset Sosial. Bandung: Mandar maju

Kaplan D. Dan Manners R.A. 2002. Teori Budaya. Terjemahan Landung Simatupang, Yogyakarta: Pustaka Pelajar.

Koentjaraningrat. 2003. Pengantar Antropologi I. Jakarta: Rineka Cipta

..........2002. Pengantar Antropologi II. Jakarta:Rineka Cipta 1983. Metode-Metode Penelitian Masyarakat. Jakarta : Gramedia

Machwe, Prabhakar. 2000. Kontribusi Hindu terhadap Ilmu Pengetahuan dan Peradaban. Terjemahan I.B.P. Suamba. Denpasar: Widya Dharma

Moloeng, Lexy J. 1994. Metode Penelitian Kualitatif. Bandung: PT Remaja Rosdakarya

Muhadjir, Noeng. 2002. Metodologi Penelitian Kualitatif. Yogyakarta: Rake Sarasin Netra, A.A. Oka. 1994. Tuntunan Dasar Agama Hindu. Jakarta: Bimas Hindu dan Buddha Nottingham, Elizabeth K. 2002. Agama dan Masyarakat Suatu pengantar Sosiologi Agama. Terjemahan Abdul Muis Naharong. Jakarta: PT Raja Grasindo Persada.

Palmer, Richard E. 2003. Hermeneutika Teori baru Mengenai Interpretasi. Terjemahan Musnur Hery \& damanhuri Muhammed. Yogyakarta: Pustaka Pelajar

Pandit, Bansi. 2006. Pemikiran Hindu: Pokok-Pokok Pikiran Agama Hindu dan Filsafat. Surabaya: Paramita.

Soekmono. 1981. Pengantar Sejarah Kebudayaan Indonesia 1. Yogyakarta: Kanisius 1981. Pengantar Sejarah Kebudayaan Indonesia 2. Yogyakarta: Kanisius 1981. Pengantar Sejarah Kebudayaan Indonesia 3. Yogyakarta: Kanisius

Suastika, I Made. 2002. "Pentingnya Pemahaman Nilai Budaya dalam Dinamika Kesusastraan Bali” dalam buku Masalah Budaya dan Pariwisata dalam 
Pembangunan. Suntingan I Gusti Ngurah Bagus. Denpasar: P.S. Magister Kajian Budaya Unud.

Sumaryono, E. 1999. Hermeneutik Sebuah Metode Filsafat. Yogyakarta: Kanisius

Weber, Max. 2002. Sosiologi Agama. Terjemahan Muhammad Yamin. Yogyakarta: IRCiSoD 